\title{
PENGEMBANGAN MODEL PENGELOLAAN SUAKA PERIKANAN DI PERAIRAN UMUM DARATAN BERBASIS KO MANAJEMEN
}

\author{
Zahri Nasution $^{1)}$ dan Mas Tri Djoko Sunarno ${ }^{2)}$ \\ 1) Peneliti pada Balai Besar Riset Sosial Ekonomi Kelautan dan Perikanan, Jakarta \\ 2) Peneliti pada Pusat Riset Perikanan Tangkap, Ancol-Jakarta \\ Teregristrasi I tanggal: 6 Pebruari 2007; Diterima setelah perbaikan tanggal: 26 Maret 2008; \\ Disetujui terbit tanggal: 25 April 2008
}

\begin{abstract}
ABSTRAK
Pendekatan pengelolaan sumber daya perikanan yang berakar pada masyarakat lebih diarahkan langsung pada masalah-masalah yang berhubungan dengan pengelolaan dan pembangunan perikanan yang dalam pelaksanaannya bernaung di bawah program pembangunan perikanan nasional yang mengikutsertakan aspek-aspek ilmu ekonomi, antropologi, hukum, dan politik, di samping ilmu limnologi. Berbagai kajian yang telah dilakukan, baik di Sumatera (Sumatera Selatan dan Jambi) maupun Kalimantan (Kalimantan Barat) dan berbagai informasi lain menunjukkan bahwa pengelolaan suaka perikanan di perairan umum daratan sudah saatnya diterapkan, jika menginginkan pemanfaatan sumber daya perikanan perairan umum daratan tersebut secara bertanggungjawab. Pola ko manajemen dalam hal ini merupakan suatu alternatif pola kerja sama antara pemerintah dan masyarakat. Pelaksanaan dan pengaturannya dilaksanakan oleh masyarakat, sehingga pemerintah hanya berfungsi sebagai fasilitator. Dalam implementasinya, penetapan suaka perikanan, secara tekhnis mengikuti beberapa kaidah fungsi biologi dan ekologis yang sudah ada. Sementara itu, mula-mula secara ekonomi suaka perikanan berdampak terhadap upaya mempertahankan dan atau meningkatkan pendapatan masyarakat nelayan, dan pada akhirnya berdampak secara sosial dan kelembagaan. Pengaturan pengelolaan dan pemanfaatan sumber daya perikanan, termasuk di dalam pengembangan model pengelolaan suaka perikanan, dapat dilakukan dengan mengikuti tahapan yaitu identifikasi dan penetapan kelompok kerja pengelola sumber daya perikanan, termasuk suaka perikanan di mana pemerintah bertindak sebagai fasilitator. Penetapan rencana pengelolaan suaka perikanan, termasuk unsur-unsur batas yurisdiksi, hak dan kewajiban, dan aturan representasi terkait dengan kegiatan penangkapan ikan dilakukan oleh masyarakat nelayan. Selain itu, penetapan pengawas dan sistem pengawasan pengaturan, termasuk aturan main penegakan peraturan yang telah ditetapkan pada tingkat masyarakat patut diperhatikan sebelum sampai dengan pada sistem hukum positif. Penetapan pengaturan berfungsi sebagai upaya mempertahankan kualitas biologi dan ekologi perairan umum daratan, di samping pengaturan penggunaan alat tangkap dan musim penangkapan yang diperbolehkan.
\end{abstract}

KATAKUNCI: suaka perikanan, perairan umum daratan, ko manajemen

ABSTRACT: Development of management model of fisheries reserve in inland waters based on co management pattern. By: Zahri Nasution and Mas Tri Djoko Sunarno

Approach of fisheries resource management using society base is addressed directly to problems related to management and development of fisheries. In

Korespondensi penulis:

JI. KS.Tubun Petamburan VI, E-mail: zahri_nas@yahoo.com 


\begin{abstract}
implementation it, follows the programs of national fisheries development involving aspects of economics, anthropologic, law, and politics as well as limnology. Many studies conducted in South Sumatera, Jambi, and West Kalimantan and other information concluded that management of fisheries reserve in inland waters could be applied to attain responsible fisheries management in those areas. Co management in this case is an alternative cooperation between the government and society groups. The society is responsible to execution and management those program, so the government plays only as a facilitator. In its application, decision of fisheries reserve technically has to follow existing biological and ecological functions. In the mean time, economical aspect initially of the fisheries reserve have to give an impact on an effort of defending and or increasing fisher income and in the last step, also impacts on aspects of social and institution as well. Organizations of management and utilization of fisheries resource including development of its model could be done following a protocol such as identification and decision of working group as a manager of the fisheries resource e. q. fisheries reserve where the government acts as facilitator. Decision of management plan of fisheries reserve e. q. jurisdiction borders, authority and obligation and representative regulation related to fish catch activities is conducted by the fishers. Besides, decision of observer and regulation system of observation including applying regulations have been made in the society level should be concerned before attaining positive laws. The decision of regulation functions as an effort of sustaining biological and ecological qualities of inland waters besides allowed regulation of using gears and seasonal catch.
\end{abstract}

\title{
KEYWORDS: fisheries reserve, inland waters, co management
}

\section{PENDAHULUAN}

Sumber daya perikanan perairan umum di Indonesia kondisinya terabaikan, baik yang terkait dengan peranan penting, penempatan prioritas dalam pembangunan, maupun anggapan sebagai tempat pembuangan limbah serta informasi tentang potensinya. Padahal, sumber daya perikanan perairan umum daratan di Indonesia mempunyai potensi yang besar, baik potensi lahan (13,85 juta ha), keanekaragaman jenis ikan (sekitar 2.000 jenis), maupun potensi produksi ikan yang mencapai 3,05 juta ton per tahun (Kartamihardja et al., 2007). Padahal, jika diamati dan dipelajari lebih jauh, sumber daya perikanan perairan umum daratan di Indonesia tidak berperan sebagai sumber penghasil ikan konsumsi bagi masyarakat, tetapi juga sebagai sumber kehidupan masyarakat (terutama nelayan dan pedagang) dan pemerintah daerah (sebagai sumber pendapatan asli daerah) (Nasution et al., 1992).

Pengelolaan sumber daya perikanan perairan umum daratan di Indonesia sangat beragam dari satu wilayah ke wilayah lain baik antar propinsi maupun kabupaten, meskipun telah ada pengaturan yang bersifat nasional. Peraturan nasional tersebut dapat berupa campur tangan pemerintah dalam pengaturannya seperti kewilayahan penggunaan tanah, reboisasi, pengaturan suaka perikanan, dan lain-lain (Hartwick \& Olewiler, 1986). Tetapi, perbedaan pengaturan tersebut tercermin dari adanya Peraturan Daerah masingmasing dan adat istiadat yang diberlakukan misalnya pada tingkat desa atau pun kecamatan. Sementara itu, pendekatan pengelolaan sumber daya perikanan yang berakar pada masyarakat lebih banyak diarahkan langsung kepada masalahmasalah yang berhubungan dengan 
pengelolaan dan pembangunan perikanan yang tetap dilaksanakan di bawah program pembangunan perikanan Nasional (Pomeroy, 1991), di dalamnya termasuk unsur-unsur ilmu ekonomi, antropologi, hukum, dan politik (Pomeroy, 1993), di samping aspek limnologi. Kemudian, karakteristik sosial dan kultural penting pula dipelajari dalam pembangunan perikanan terutama yang berskala kecil (Pollnac, 1988).

Konsep ko manajemen (pengelolaan bersama) memberikan pengertian sebagai suatu pengaturan kemitraan dengan menggunakan kemampuan dan minat nelayan lokal dan masyarakat yang dilengkapi oleh kemampuan pemerintah untuk menyediakan perangkat hukum yang memungkinkan dan bantuan lainnya yang dapat diterapkan dalam pengelolaan suaka perikanan (Dahuri et al., 1998; Anonimus, 2000). Pelaku perikanan kunci dalam pengelolaan bersama adalah yang terlibat langsung dengan penggunaan sumber daya, yaitu nelayan dan anggota keluarga.

Pengelolaan suaka perikanan di Indonesia saat ini terdapat berbagai pola antara lain yang dikelola secara dominan oleh pemerintah seperti di Sumatera Selatan dan yang dominan dikelola oleh masyarakat seperti yang terdapat di Kalimantan Barat. Pola pengelolaan ini masing-masing mempunyai kelebihan dan kekurangan. Dalam hal ini, berdasarkan pada hasil penelitian Hoggarth et al. (1999) dapat disimpulkan bahwa penggabungan ke-2 pola pengelolaan tersebut (ko manajemen) merupakan hasil maksimum yang didapatkan oleh masyarakat tanpa mengabaikan kelestarian sumber daya perikanan dan peranan pemerintah. Hal ini terlihat pula dari berbagai kajian lain, khususnya daerah suaka perikanan di wilayah Propinsi Sumatera Selatan dan Jambi, menunjukkan bahwa suaka perikanan tetap lebih baik hasilnya dengan penerapan pola ko manajemen (Nasution et al., 2002).

Dengan demikian, dapat dikatakan bahwa berdasarkan pada berbagai kajian yang telah dilakukan baik di Sumatera (Sumatera Selatan dan Jambi) maupun Kalimantan (Kalimantan Barat), dan berbagai informasi lain, maka diketahui bahwa pengembangan model pengelolaan suaka perikanan di perairan umum daratan Indonesia sudah saatnya dilakukan melalui penerapan pola ko manajemen, jika menginginkan pemanfaatan sumber daya perikanan perairan umum daratan yang bertanggungjawab.

\section{KELOMPOK MASYARAKAT PENGELOLA SUAKA PERIKANAN}

Keberadaan kelompok kerja, baik yang terdiri atas anggota masyarakat atau gabungan antara masyarakat dan pemerintah yang bekerja mempersiapkan penyusunan rencana pengelolaan sumber daya perikanan, menggambarkan adanya kerja sama antar pemanfaat sumber daya perikanan di wilayah perairan umum daratan yang dikelola. Kelompok kerja yang merupakan gabungan antara anggota masyarakat dan unsur-unsur pemerintah yang terkait hanya terdapat pada pengelolaan suaka perikanan yang menerapkan pola ko manajemen. Di Danau Arang-Arang, kelompok kerja ini terdapat dalam bentuk lembaga yaitu Lembaga Musyawarah Desa. Lembaga Musyawarah Desa ini tersusun atas berbagai perwakilan anggota masyarakat, yaitu para Ketua Rukun Warga, para Ketua Rukun Tetangga, para Kepala Dusun, unsur kepemudaan, Lembaga Ketahanan Masyarakat Desa, dan tokoh masyarakat lain termasuk Ketua Keamanan Rakyat dan Ketua Danau (Ketua Kelompok Nelayan). Berfungsinya atau tidak kelompok kerja dalam rangka 
penyusunan rencana pengelolaan suaka perikanan tergambar dari frekuensi pertemuan yang diadakan beserta topik yang dibicarakan dalam pertemuan tersebut. Untuk penerapan ko manajemen yang dilakukan di Desa Arang-Arang, Jambi, pertemuan yang diadakan oleh kelompok kerja penyusunan rencana pengelolaan sumber daya perikanan minimal 2 kali dalam 1 tahun yang dilaksanakan di rumah Kepala Desa (Nasution et al., 2002).

Adapun topik pertemuan yang tetap adalah menentukan besar pembayaran sewa perairan, baik bagi masyarakat desa setempat maupun masyarakat luar Desa Arang-Arang serta penetapan hari berkarang yang pertama pada saat air menjelang surut. Topik-topik lain tergantung kepada adanya usul dari masyarakat nelayan atau pengaturan lapangan lain yang diperlukan, termasuk di dalam penetapan Ketua Danau yang ditetapkan 2 tahun sekali. Di lain pihak, pada perairan umum daratan yang dikelola dengan pola yang didominasi oleh pemerintah, pertemuan seperti ini dilaksanakan oleh unsur pemerintah, tidak mengikutsertakan unsur dari nelayan. Dengan demikian, aspirasi nelayan tidak dapat tertampung. Berfungsi atau kurang berfungsinya kelembagaan terkait dengan pengelolaan sumber daya perikanan termasuk pengelolaan suaka perikanan sesuai dengan tugas dan fungsi masing-masing tergambar dari pendapat masyarakat nelayan. Tugas dan fungsi tersebut misalnya bagi Dinas Perikanan Propinsi Jambi dan Dinas Perikanan Kabupaten Batanghari telah melakukan penunjukan petugas jaga suaka perikanan yang disesuaikan dengan hasil musyawarah yang dilakukan oleh lembaga yang ada pada tingkat masyarakat (Lembaga Musyawarah Desa). Begitu pula Kepala Desa sebagai kelembagaan tingkat desa telah turut pula mengesahkan apa yang menjadi hasil musyawarah (Lembaga
Musyawarah Desa) guna pengelolaan sumber daya perikanan (termasuk pengelolaan suaka perikanan).

Pengaturan pengelolaan sumber daya perikanan yang disahkan oleh Kepala Desa setelah diadakan musyawarah (Lembaga Musyawarah Desa) dan dibuat dalam bentuk tertulis antara lain adalah penetapan hari berkarang dan larangan penangkapan ikan secara perorangan dengan menggunakan alat tangkap jaring dan jala sebelum ditetapkan hari berkarang. Tindakan pengamanan suaka perikanan dengan menerapkan pola ko manajemen di Danau Arang-Arang, Jambi dapat mengikutsertakan masyarakat nelayan setempat yaitu sekitar 15 orang sebagai anggota masyarakat yang membantu petugas jaga suaka perikanan tersebut di lapangan. Akibat lebih lanjut adalah menuju kepada bertambah efektifnya fungsi suaka perikanan secara keseluruhan terhadap sumber daya perikanan pada perairan yang dikelola dengan pola ko manajemen. Berbeda hal pada pengelolaan suaka perikanan dengan pola ko manajemen, keberadaan dan partisipasi aktif masyarakat nelayan dalam penyusunan rencana pengelolaan suaka perikanan, baik yang disampaikan secara lisan ataupun tertulis, sangat diperhatikan.

Hasil kajian di perairan umum daratan di Jambi menunjukkan bahwa $74 \%$ masyarakat nelayan yang melaksanakan penangkapan ikan pada perairan umum daratan yang menerapkan suaka perikanan dengan pola ko manajemen menganggap penting keberadaan kelompok kerja pengelolaan sumber daya perikanan di mana di dalamnya termasuk pengelolaan suaka perikanan (Nasution et al., 2002). Sementara itu, pada masyarakat nelayan perairan umum daratan yang menerapkan suaka perikanan yang dikelola dengan pola yang didominasi oleh pemerintah hanya 
23\% yang menganggap penting keberadaan kelompok kerja penyusunan rencana pengelolaan sumber daya perikanan ini atas dasar bahwa masyarakat nelayan setempat dapat menyampaikan aspirasi baik secara lisan maupun secara tertulis pada pemerintah setempat melalui kelompok kerja tersebut (Lembaga Musyawarah Desa).

Masyarakat nelayan di Desa ArangArang menganggap penting pengendalian gulma yang berada dan menutupi sebagian besar perairan Danau Arang-Arang. Dengan adanya kelompok kerja, maka pembiayaan pengelolaan suaka perikanan di perairan Danau Arang-Arang dapat memanfaatkan dana kas masyarakat nelayan yang dikumpulkan dari pembayaran izin penangkapan. Hal ini didukung pula oleh keadaan bahwa petugas jaga suaka perikanan pada perairan umum daratan yang dikelola dengan pola ko manajemen diambil dari salah seorang yang ditokohkan masyarakat, sedangkan pada pengelolaan suaka perikanan yang dikelola dengan dominasi pemerintah tidak mempertimbangkan pengaruh aspek sosial seseorang penjaga suaka perikanan terhadap masyarakat nelayan. Hal ini bersesuaian dengan azas aturan representasi yang dikatakan oleh Pakpahan (1989) yang merupakan salah satu unsur penyusun kelembagaan yang penting dalam mencapai tujuan penetapan kelembagaan (dalam hal ini suaka perikanan).

Kemudian, 66\% masyarakat nelayan yang melaksanakan penangkapan ikan pada perairan umum daratan yang menerapkan suaka perikanan dengan pola ko manajemen mengatakan bahwa kelembagaan terkait dalam pengelolaan sumber daya perikanan telah berfungsi sesuai dengan tugas dan fungsi masingmasing. Di lain pihak, pada masyarakat nelayan perairan umum daratan yang menerapkan suaka perikanan yang dikelola dengan pola yang didominasi oleh pemerintah hanya $45 \%$ yang mengatakan bahwa kelembagaan terkait berfungsi sesuai dengan tugas dan fungsinya. Sementara itu, 55\% masyarakat lainnya mengatakan bahwa kelembagaan terkait belum disesuaikan dengan tugas dan fungsinya, termasuk di dalamnya belum mengikutsertakan anggota masyarakat nelayan atau organisasi nelayan dalam musyawarah pengelolaan suaka perikanan. Selanjutnya, 79\% masyarakat nelayan yang melaksanakan penangkapan ikan pada perairan umum daratan yang menerapkan suaka perikanan dengan pola ko manajemen mengatakan sangat aktif untuk berpartisipasi dalam pengelolaan sumber daya perikanan, termasuk pengelolaan suaka perikanan perairan umum daratan. Hal ini sesuai dengan prinsip kelembagaan dalam ko manajemen yang mengatakan bahwa setiap aturan permainan dapat diubah asalkan telah merupakan suatu kesepakatan bagi pengguna dan pembuat aturan itu sendiri (Pomeroy, 1991).

\section{EFEKTIVITAS KELEMBAGAAN PENGELOLA SUAKA PERIKANAN}

Efektivitas kelembagaan terkait dengan pengelolaan suaka perikanan melalui pola ko manajemen dan pola pengelolaan yang didominasi pemerintah dalam penyusunan rencana pengelolaan suaka perikanan terlihat dari unsur-unsur batas yurisdiksi, hak dan kewajiban, dan aturan representasi. Kelembagaan yang dimaksudkan dalam hal ini adalah Dinas Perikanan Propinsi, Dinas Perikanan Kabupaten, Kepala Desa, Lembaga Ketahanan Masyarakat Desa, Lembaga Musyawarah Desa, dan kelembagaan desa Iain seperti Kelompok Nelayan dan Kelompok Pemuda misalnya pada perairan 
umum daratan yang dikelola dengan penerapan suaka perikanan pola ko manajemen. Dinas Perikanan Propinsi Jambi dan Dinas Perikanan Kabupaten Batanghari telah menetapkan kebijakan pengelolaan suaka perikanan dan petugas jaga suaka perikanan. Masing-masing pengaturan tersebut dalam bentuk Surat Keputusan Kepala Dinas Perikanan Propinsi Jambi untuk penetapan petugas jaga suaka perikanan dan Bupati Kabupaten Batanghari untuk penetapan Danau ArangArang sebagai suaka perikanan.

Di lain pihak, Lembaga Musyawarah Desa dengan musyawarah menetapkan pengaturan tentang penangkapan ikan di perairan Danau Arang-Arang yang selanjutnya disahkan oleh Kepala Desa. Pengaturan tersebut antara lain izin penangkapan ikan baik untuk masyarakat Desa Arang-Arang maupun luar desa. Penetapan sewa bagi masyarakat luar desa untuk melakukan penangkapan ikan di Danau Arang-Arang merupakan cara yang ditempuh untuk membatasi nelayan luar desa untuk beroperasi di Danau ArangArang. Hal ini sesuai dengan prinsip bahwa dalam ko manajemen terjadi pembagian tanggung jawab dan wewenang antara pemerintah dan masyarakat lokal dalam pengelolaan sumber daya alam (Pomeroy \& Williams, 1994). Di samping itu, peraturan mengenai penegakan hukum terhadap pelanggaran yang dilakukan oleh masyarakat luar desa ditetapkan tanpa melalui peringatan terlebih dahulu yang dibedakan terhadap masyarakat desa yang terlebih dahulu mendapatkan peringatan. Dalam hal ini tidak ada intervensi Dinas Perikanan atau Kepolisian atau pihak pemerintah lain dalam rangka penetapan sanksi bagi pelanggaran terhadap aturan yang ada. Sebagian besar atau 84\% masyarakat nelayan yang melaksanakan penangkapan ikan pada perairan umum daratan yang menerapkan suaka perikanan dengan pola ko manajemen mengatakan bahwa kelembagaan yang terkait dalam pengelolaan sumber daya perikanan, termasuk pengelolaan suaka perikanan perairan umum daratan sangat efektif. Artinya setiap kelembagaan yang terkait tersebut bertugas dan berfungsi sesuai dengan tugas dan fungsinya masingmasing. Dalam hal ini, masyarakat nelayan menganggap bahwa meskipun perairan umum daratan yang ada di desa tetapi diperlukan campur tangan pemerintah.

Campur tangan pemerintah yang diperlukan masyarakat nelayan antara lain pengendalian tumbuhan yang menutupi perairan baik yang terdapat pada perairan umum daratan maupun suaka perikanan. Di samping itu, nelayan mencontohkan dalam hal penebaran kembali ikan ke perairan umum daratan dalam rangka penambahan populasi ikan di perairan umum daratan tersebut. Hal ini sejalan dengan pernyataan bahwa pemerintah perlu capur tangan terutama terhadap pengelolaan sumber daya perikanan yang sifatnya milik bersama (Crutchfield, 1987). Di lain pihak, pada pengelolaan suaka perikanan yang didominasi oleh pemerintah, $68 \%$ masyarakat nelayan berpendapat bahwa kelembagaan yang terkait dalam pengelolaan sumber daya perikanan perairan umum daratan kurang efektif. Sementara itu, 32\% masyarakat nelayan mengangap kelembagaan tersebut tidak aktif sama sekali. Dalam hal ini berpendapat bahwa pemerintah hanya memungut hasil sewa perairan, sedangkan konservasi sumber daya perikanan sangat kurang diperhatikan.

Koordinasi perencanaan pengelolaan suaka perikanan antara lembaga terkait dan atau pemanfaat sumber daya perikanan tersebut, termasuk pula di dalamnya adalah partisipasi aktif masyarakat nelayan baik berupa usul pada Ketua Danau atau Ketua 
Kelompok Nelayan (atribut ke-2) menunjukkan bahwa sebagian besar atau $53 \%$ masyarakat nelayan yang melaksanakan penangkapan ikan pada perairan umum daratan yang menerapkan suaka perikanan dengan pola ko manajemen mengatakan bahwa koordinasi perencanaan pengelolaan suaka perikanan telah berjalan sangat baik termasuk partisipasi masyarakat nelayan dalam perencanaan tersebut. Hal ini memberikan pengertian bahwa pengelolaan sumber daya perikanan, termasuk pengelolaan suaka perikanan pada pola ko manajemen cukup terencana dan masyarakat turut serta dalam perencanaan tersebut. Berbeda hal pada pengelolaan suaka perikanan yang didominasi oleh pemerintah, $68 \%$ masyarakat nelayan berpendapat bahwa tidak mengetahui apakah pernah terjadi koordinasi dalam perencanaan pengelolaan suaka perikanan. Tetapi masyarakat nelayan tidak pernah berpartisipasi dalam perencanaan tersebut. Dalam hal ini berpendapat bahwa mengelola suaka perikanan merupakan tugas dan kewajiban pemerintah.

\section{KESADARAN, MOTIVASI, DAN PENDAPATAN MASYARAKAT NELAYAN}

Penerapan konsep ko manajemen dalam pelaksanaan pengelolaan suaka perikanan di perairan umum daratan terdiri atas beberapa variabel, yaitu kesadaran dan tanggung jawab masyarakat dalam menjaga dan memelihara suaka perikanan, motivasi masyarakat dalam tahapan dan proses pengelolaan suaka perikanan, bentuk dan variasi pemanfaatan sumber daya perikanan yang lestari oleh masyarakat nelayan, pengakuan terhadap hak hukum tradisional atau masyarakat lokal dalam pelaksanaan pengelolaan suaka perikanan, dan tingkat pendapatan masyarakat nelayan. Tanggung jawab masyarakat nelayan dalam menjaga dan memelihara suaka perikanan yang ada dicatat dalam bentuk aplikasi antara lain tidak menggunakan racun atau tuba atau listrik dalam melaksanakan penangkapan ikan. Di samping itu, juga turut menjaga kegiatan yang dilaksanakan nelayan lain di perairan pada waktu yang bersamaan dengan pelaksanaan penangkapan ikan. Sebagian besar atau 82\% masyarakat nelayan yang melaksanakan penangkapan ikan pada perairan umum daratan yang menerapkan suaka perikanan dengan pola ko manajemen mengatakan bahwa menyadari dan merasa sangat bertanggungjawab dalam menjaga dan memelihara suaka perikanan yang ada di desa atau perairan tempat melaksanakan penangkapan ikan. Hal ini memberikan pengertian bahwa pengelolaan sumber daya perikanan, penjagaan dan pemeliharaan serta pengelolaan suaka perikanan pada pola ko manajemen tidak hanya dilakukan oleh 1 orang.

Kesadaran dan tanggung jawab masyarakat nelayan tersebut tercermin dari hasil survei yang menunjukkan bahwa pada Desa Arang-Arang terdapat minimal 4 anggota masyarakat nelayan yang dipercaya Ketua Danau untuk mengawasi penangkapan ikan. Jika ada kejadian tentang pencurian ikan di suaka perikanan atau seseorang mencuri ikan milik nelayan lain, maka orang yang dipercaya tersebut melapor kepada Ketua Danau untuk selanjutnya ditindaklanjuti. Hal ini sesuai dengan hasil wawancara dengan Kepala Desa dan Ketua Danau serta Ketua Keamanan Rakyat yang dapat disimpulkan bahwa sistem pengawasan suaka perikanan yang diterapkan di Desa ArangArang adalah sistem pengawasan yang dilaksanakan oleh masyarakat secara bersama. Kemudian dalam pelaksanaan di lapangan dibantu oleh 15 orang yang dipercaya oleh Ketua Keamanan dan Ketua Danau sebagai pengawas lapangan yang utamanya untuk pengamanan suaka 
perikanan. Berbeda hal pada pengelolaan suaka perikanan yang didominasi oleh pemerintah, untuk atribut pertama, sebagian besar atau 73\% masyarakat nelayan terlihat tidak menyadari dan tidak merasa bertanggungjawab terhadap penjagaan dan pemeliharaan suaka perikanan. Seperti dikatakan di atas bahwa dalam hal ini berpendapat bahwa mengelola suaka perikanan merupakan tugas dan kewajiban pemerintah.

Motivasi masyarakat nelayan dalam tahapan pengelolaan suaka perikanan dan faktor pendorong nelayan untuk turut serta dalam menjaga dan memelihara suaka perikanan yang ada di wilayah perairan umum daratan antara lain nelayan mengatakan bahwa agar mendapatkan ikan yang berukuran besar sehingga harganya mahal dan usulan lainnya antara lain supaya tidak menangkap benih ikan seperti gabus dan toman, dengan nilai yang dikuantifikasi. Atribut yang menunjukkan bahwa sebagian besar atau 74\% masyarakat nelayan yang melaksanakan penangkapan ikan pada perairan umum daratan yang menerapkan suaka perikanan dengan pola ko manajemen memiliki motivasi yang merupakan dorongan untuk turut serta menjaga dan memelihara suaka perikanan. Sebagai contoh masyarakat nelayan menginginkan agar ikan-ikan yang ditangkapi berukuran besar-besar sehingga jika dijual harganya mahal. Di samping itu, masyarakat nelayan di wilayah ini tidak pernah melaksanakan hal-hal yang dilarang oleh aturan desa dan pemerintah. Hal ini memberikan pengertian bahwa penjagaan dan pemeliharaan serta pengelolaan suaka perikanan pada pola ko manajemen juga ada suatu motivasi yang menguntungkan secara bersama, yaitu agar masyarakat nelayan mempunyai sumber pendapatan sepanjang tahun.
Aplikasi dari motivasi masyarakat nelayan tersebut tercermin dari hasil survei yang menunjukkan bahwa pada Desa Arang-Arang, anggota masyarakat nelayan sama-sama mengetahui bahwa tidak menangkapi ikan-ikan yang berukuran kecil guna menjaga populasi ikan agar tumbuh. Di samping itu, masyarakat nelayan juga tidak menebang hutan rawa yang ada di sekitar suaka perikanan. Karena hutan rawa tersebut berguna untuk menyediakan tempat berlindung dan berdiam bagi ikan dan populasi (Welcomme, 1979; 1985; Utomo \& Nasution, 1995). Berbeda hal pada pengelolaan suaka perikanan yang didominasi oleh pemerintah, sebagian besar atau 64\% masyarakat nelayan terlihat kurang mempunyai motivasi untuk turut menjaga dan memelihara suaka perikanan. Bahkan 36\% masyarakat tersebut tidak mempunyai motivasi untuk menjaga dan memelihara suaka perikanan. Kemudian, pada perairan umum daratan yang pengelolaannya didominasi pemerintah, sebagian besar atau 45\% masyarakat nelayan tidak memperhatikan kelestarian sumber daya perikanan sama sekali. Hanya $18 \%$ yang mempertimbangkan kelestarian sumber daya perikanan. Contoh cara penangkapan ikan yang dilaksanakan masyarakat yang tidak memperhatikan kelestarian sumber daya perikanan antara lain adalah penangkapan anak-anak ikan toman dan gabus menggunakan jala (cast net) pada saat air besar yang sekaligus menangkap induk. Di samping itu, masyarakat nelayan juga menangkap ikan tambakan yang sedang bertelur di perairan lebak.

Apakah terdapat pengakuan terhadap hak-hak hukum tradisional atau pengaturan-pengaturan sebelumnya yang berasal dari masyarakat lokal dan saat ini menjadi pengaturan dalam pelaksanaan 
pengelolaan suaka perikanan ditandai dengan adanya pengaturan yang berlaku sejak lama sampai dengan saat ini. Pengaturan ini diketahui dengan adanya penambahan pengaturan yang dilakukan dalam penyusunan rencana pengelolaan suaka perikanan misalnya dalam rapat Lembaga Musyawarah Desa yang menunjukkan bahwa sebagian besar atau $58 \%$ masyarakat nelayan yang melaksanakan penangkapan ikan pada perairan umum daratan yang menerapkan suaka perikanan dengan pola ko manajemen mengatakan bahwa terdapat pengakuan terhadap hak hukum tradisional pada penerapan pola ko manajemen (Nasution et al., 2002). Hanya 16\% masyarakat nelayan yang mengatakan tidak terdapat pengakuan terhadap hak hukum tradisional.

\section{UPAYA MEMPERTAHANKAN KUALITAS BIOLOGI DAN EKOLOGI PERAIRAN}

Hasil riset menunjukkan bahwa baik pada perairan umum daratan yang menerapkan suaka perikanan dengan pola ko manajemen maupun dengan pola pengelolaan yang didominasi oleh pemerintah sama-sama terdapat ukuran individu ikan yang mengecil untuk 7 jenis ikan yang sama. Kemudian produktivitas hasil tangkapan nelayan yang digambarkan dengan keadaan jumlah hasil tangkapan ikan per satuan waktu yang sama dari tahun ke tahun juga menurun pada ke-2 jenis pola pengelolaan suaka perikanan tersebut, baik pada perairan umum daratan yang menerapkan suaka perikanan dengan pola ko manajemen maupun dengan pola pengelolaan yang didominasi oleh pemerintah sama-sama terdapat penurunan produktivitas hasil tangkapan nelayan, tetapi kondisi penurunan drastis terdapat pada perairan umum yang pengelolaan didominasi oleh pemerintah.
Sementara kondisi ekologis perairan, baik pada perairan yang dikelola melalui penerapan suaka perikanan dengan pola ko manajemen dan pola pengelolaan yang didominasi oleh pemerintah, dilihat melalui keberadaan keadaan yang memberikan dukungan bagi siklus kehidupan ikan, baik untuk spawning ground (daerah pemijahan), nursery ground (daerah untuk pengasuhan), roaming site (daerah untuk bergerak bebas), feeding ground (daerah untuk tempat mencari makan), dan refuge site (daerah untuk tempat berlindung). Keadaan yang memberikan dukungan bagi siklus kehidupan ikan tersebut adalah relatif sama. Namun, untuk daerah pemijahan, 18\% nelayan mengatakan sedikit daerah pemijahan tersebut pada perairan yang suaka perikanan dikelola dengan pola yang didominasi oleh pemerintah. Pendapat serupa terlihat untuk daerah asuhan dan daerah untuk tempat berlindung (Nasution et al., 2002).

\section{REKOMENDASI}

Riset yang berkaitan dengan pengelolaan sumber daya perikanan dan bagaimana peranan dan pengelolaan suaka perikanan perairan umum daratan, terutama kaitannya dengan aspek sosial, ekonomi, dan kelembagaan, telah beberapa kali di lakukan. Namun demikian, hasil riset tersebut belum ditindaklajuti dalam suatu pelaksanaan program lembaga teknis, baik di tingkat propinsi maupun kabupaten. Padahal, secara nyata telah diketahui dan dikatakan bahwa suaka perikanan penting berperan terutama kaitannya dengan upaya mempertahankan tingkat pendapatan masyarakat nelayan perairan umum daratan (Nasution, 1990: Nasution et al., 1992). Sebagian besar masyarakat nelayan yang melaksanakan penangkapan ikan pada perairan umum daratan yang menerapkan suaka perikanan dengan pola 
ko manajemen lebih mengetahui bahwa manfaat sumber daya perikanan, bukan hanya didapatkan oleh masyarakat nelayan, tetapi juga termasuk pedagang, masyarakat desa sekitar dan pemerintah daerah setempat (desa dan ataupun kabupaten).

Masyarakat nelayan menganggap penting keberadaan kelompok kerja pengelolaannya sumber daya perikanan, dan di dalam termasuk pengelolaan suaka perikanan dalam suatu pertemuan yang dilakukan oleh kelompok kerja yang mengikutsertakan perwakilan dari masyarakat nelayan, menyadari dan merasa sangat bertanggungjawab dalam menjaga dan memelihara suaka perikanan yang ada di desa atau perairan tempat melaksanakan penangkapan ikan. Di samping itu, masyarakat nelayan memiliki motivasi yang merupakan dorongan untuk turut serta menjaga dan memelihara suaka perikanan. Kemudian, dalam pola ko manajemen terdapat pengakuan terhadap hak hukum tradisional tetapi pada perairan umum daratan yang pengelolaannya didominasi pemerintah, sebagian besar (72\%) masyarakat nelayan mengatakan tidak terdapat pengakuan terhadap hak hukum tradisional.

Baik perairan umum daratan yang menerapkan suaka perikanan dengan pola ko manajemen maupun dengan pola pengelolaan yang didominasi oleh pemerintah sama-sama ditemui pengecilan ukuran individu 7 jenis ikan yang sama dan penurunan produktivitas hasil tangkapan nelayan. Tetapi kondisi penurunan drastis terdapat pada perairan umum daratan yang pengelolaan didominasi oleh pemerintah. Sementara itu, untuk daerah pemijahan, $18 \%$ nelayan mengatakan sedikit pada perairan yang suaka perikanan dikelola dengan pola yang didominasi oleh pemerintah. Begitu pula untuk daerah asuhan dan daerah untuk tempat berlindung. Bahkan, jika sumber daya perikanan perairan umum daratan diperhatikan dan dikelola dengan benar, maka akan terjadi peningkatan produksi minimal $20 \%$ dari fungsi ekologis (Kartamihardja et al., 2007).

Dengan demikian, sudah saatnya
pengelolaan suaka perikanan di
perairan umum daratan dikembangkan
menggunakan model pengelolaan yang
menerapkan pola ko manajemen. Pola ko
manajemen dalam hal ini adalah kerja sama
antara pemerintah dan masyarakat dengan
pengorganisasian yang dilaksanakan oleh
masyarakat dan pengaturan oleh
masyarakat, sehingga pemerintah hanya
berfungsi sebagai fasilitator. Suaka
perikanan perairan umum perlu ditetapkan
segera sebagai pertimbangan pola
pengelolaan sumber daya perikanan secara
menyeluruh. Adapun tujuannya adalah agar
sumber daya perikanan perairan umum
daratan di Indonesia tetap dapat
dimanfaatkan sebagai sumber kehidupan
masyarakat nelayan dan sebagai upaya
pemenuhan konsumsi ikan bagi
masyarakat.

\section{STRATEGI IMPLEMENTASI KEBIJAKAN}

Berdasarkan pada hasil riset, keberhasilan model pengelolaan suaka perikanan terlihat pada penggunaan pola ko manajemen yang dilengkapi oleh kemampuan pemerintah untuk menyediakan perangkat hukum dan bantuan lainnya. Dengan adanya penerapan pola ko manajemen untuk pengelolaan suaka perikanan pada perairan umum daratan di Indonesia diharapkan akan didapatkan model pengelolaan suaka perikanan yang menghasilkan keberlanjutan sumber daya perikanan dan pendapatan masyarakat nelayan. Untuk itu, pengelolaan perairan 
seperti sungai dan rawa banjiran dalam pembangunan perikanan mengikuti pertimbangan antara lain optimasi pemanfaatan sumber daya dan keseimbangan manfaat antar pengguna (Mellquist, 1992). Hal ini dapat berupa kebijakan mempertahankan upaya penangkapan pada suatu tingkat tertentu yang berhubungan dengan tujuan tertentu (Troadec, 1992).

Dalam implementasi, pengembangan model pengelolaan suaka perikanan dilakukan dengan cara penetapan suaka perikanan, yang secara teknis mengikuti beberapa kaidah fungsi biologi dan ekologis yang sudah ada. Sementara itu, secara ekonomi berdampak terhadap upaya mempertahankan dan atau meningkatkan pendapatan masyarakat nelayan, dan pada bagian akhir berdampak secara sosial dan kelembagaan. Pengaturan pengelolaan dan pemanfaatan sumber daya perikanan, termasuk di dalam pengelolaan suaka perikanan, dapat dilakukan mengikuti tahapan sebagai berikut:

1. Identifikasi dan penetapan kelompok kerja pengelolaan sumber daya perikanan, termasuk di dalamnya pengelolaan suaka perikanan (pemerintah sebagai fasilitator).

2. Penetapan rencana pengelolaan suaka perikanan, termasuk unsur-unsur batas yurisdiksi, hak dan kewajiban, dan aturan representasi terkait dengan kegiatan penangkapan ikan yang dilakukan masyarakat nelayan.

3. Penetapan pengawas dan sistem pengawasan pengaturan, termasuk aturan main penegakan peraturan yang telah ditetapkan pada tingkat masyarakat, sebelum sampai dengan sistem hukum positif.

4. Penetapan pengaturan yang berfungsi sebagai upaya mempertahankan kualitas biologi dan ekologi perairan umum, di samping pengaturan penggunaan alat tangkap yang diperbolehkan serta musim penangkapan.

\section{DAFTAR PUSTAKA}

Anonimus. 2000. Panduan pengelolaan bersama suaka penangkapan ikan di perairan sungai dan rawa banjiran. Pusat Penelitian dan Pengembangan Perikanan bekerja sama dengan Marine Resource Assessment Group. London. UK. Jakarta.

Crutchfield, J. A. 1987. Evaluasi ekonomis pada metode alternatif dari peraturan perikanan. Hal.3-25. Dalam F. Marahudin \& I. R. Smith (Penyunting). Ekonomi Perikanan. Yayasan Obor Indonesia dan Gramedia. Jakarta.

Dahuri, R., T. Kusumastanto, N. P. Zamani, R. A. Kinseng, L. Adrianto, \& N. Wahyu. 1998. Penyusunan konsep pengelolaan sumber daya pesisir dan lautan yang berakar pada masyarakat. Laporan Akhir Kerja Sama Direktorat Jenderal Pembangunan Daerah. Departemen Dalam Negeri dengan Pusat Kajian Sumber Daya Pesisir dan Lautan. Institut Pertanian Bogor. Bogor.

Hartwick, J. M. \& N. D. Olewiler. 1986. The Economics of Natural Resource Use. Harper \& Row Publisher. New York.

Hoggarth, D. D., V. J. Cowan, A. S. Halls, M. Aeron-Thomas, J. A. McGregor, C. A. Garaway, A. I. Payne, \& R. L. Welcomme. 1999. Management guidelines for Asian floodplain river fisheries. Part 1. A Spatial, Hierarchical, and Integrated Strategy for Adaptive Co Management. FAO Fisheries Technical Paper. 384/1. Food and Agriculture Organization of the United Nations. Rome. 
Kartamihardja, E. S., K. Purnomo, \& C. Umar. 2007. Sumber daya ikan perairan umum daratan di Indonesia-terabaikan. Makalah pada Simposium Nasional Riset Kelautan dan Perikanan dalam Rangka Hari Kebangkitan Teknologi Nasional 2007. Hotel Bidakara. Jakarta. 7 Agustus 2007.

Mellquist, P. 1992. River management objectives and applications. In P. J. Boon, P. Calow., \& G. E. Petts (Eds). River Conservation and Management. John Wiley \& Son. Chichester-New York-Singapore.

Nasution, Z. 1990. Lelang lebak lebung atur nelayan. Harian Pagi Sriwijaya Post. Palembang 21 Mei. 1990.

Nasution, Z., A. D. Utomo, \& D. Prasetyo. 1992. Sosial ekonomi dan pemasaran ikan perairan umum lebak lebung di Kabupaten Ogan Komering llir, Sumatera Selatan. Prosiding Temu Karya IImiah Perikanan Perairan Umum. Palembang. 12-13 Pebruari 1992. Pusat Penelitian dan Pengembangan Perikanan. Badan Penelitian dan Pengembangan Pertanian. Departemen Pertanian. Jakarta.

Nasution, Z., A. D. Utomo, E. Dharyati, Samuel, \& Ondara. 2002. Penerapan pola ko manajemen dalam pengelolaan suaka perikanan di perairan umum. Jurnal Penelitian Perikanan Indonesia. Edisi Sosial Ekonomi. Vol.8 No.7. Hal.43-56. Badan Riset Kelautan dan Perikanan. Departemen Kelautan dan Perikanan. Jakarta.

Pakpahan, A. 1989. Kerangka analitik untuk penelitian rekayasa sosial: Persfektif ekonomi institusi. Dalam E. Pasandaran et al. Prosiding Patanas Evolusi Kelembagaan Pedesaan di Tengah
Perkembangan Teknologi Pertanian. Hal.1-18. Pusat Penelitian Agro Ekonomi. Badan Penelitian dan Pengembangan Pertanian. Departemen Pertanian. Jakarta.

Pollnac, R. B. 1988. Karakter sosial dan budaya dalam pengembangan perikanan berskala kecil. Dalam M. M.Cernea (Editor). Mengutamakan Manusia di dalam Pembangunan; Variabel-Variabel Sosiologi di dalam Pembangunan Pedesaan. Penerbit Universitas Indonesia. Jakarta.

Pomeroy, R. S. 1991. Toward a community based approach to small scale fisheries management and development. In J. J. Poggie \& R. B. Pollnac (Eds). Small Scale Fishery Development: Sociocultural Persfectives: International Center for Marine Resource Development. University of Rhode Island. Kingston. Rhode Island. U. S. A.

Pomeroy, R. S. 1993. A research framework for coastal fisheries co management institutions. NAGA. The ICLARM Quarterly. January 1993.

Pomeroy, R. S. \& M. J. Williams. 1994. Fisheries co management and small scale fisheries: A policy brief. ICLARM. Manila. 15 pp.

Troadec, J. P. 1992. Introduction to Fisheries Management: Advantages, Difficulties, and Mechanisms. FAO Fisheries Technical Paper 224. Food and Agriculture Organization of the United Nations. Rome.

Utomo, A. D. \& Z. Nasution. 1995. Evaluasi reservat dalam rangka pelestarian sumber daya perikanan di perairan umum, Kumpulan Makalah Seminar 
Pengkomunikasian Hasil Penelitian Perikanan Perairan Umum di Sumatera Selatan. Palembang 13 Maret 1995. Lolitkanwar Palembang. Pusat Penelitian dan Pengembangan Perikanan. Badan Penelitian dan Pengembangan Pertanian. Departemen Pertanian. Jakarta.
Welcomme, R. L. 1979. Fisheries Ecology of Floodplain Rivers. Longman Group Limited. London. $317 \mathrm{pp}$.

Welcomme, R. L. 1985. River Fisheries, Food and Agriculture Organization Fisheries Technical Paper. No.262. $330 \mathrm{pp}$. 